(c) Group of authors, 2017

UDC 615.033

DOI - https://doi.org/10.14300/mnnc.2017.12083

ISSN - 2073-8137

\title{
COMPARATIVE ANALYSIS OF ACTIVITY OF CYTOCHROME ISOENZYME P450 CYP2C9 IN ELDERLY AND SENILE PATIENTS AND WITH THAT IN HEALTHY VOLUNTEERS OF THE FIRST PERIOD OF MIDDLE AGE
}

\author{
Sychev D. A. ${ }^{1}$, Bordovsky S. P. ${ }^{2}$, Nikulin V. E. ${ }^{2}$, Polshina N. I. ${ }^{2}$, \\ Anikin G. S. ${ }^{2}$, Danilina K. S. ${ }^{1}$, Smirnov V. V. ${ }^{2,3}$ \\ ${ }^{1}$ Russian Medical Academy of Continuous Professional Education, Moscow, \\ Russian Federation \\ ${ }^{2}$ I. M. Sechenov First Moscow State Medical University, Russian Federation \\ ${ }^{3}$ NRC Institute of Immunology FMBA, Moscow, Russian Federation
}

\section{СОПОСТАВАЕНИЕ АКТИВНОСТИ ИЗОФЕРМЕНТА ЦИТОХРОМА Р450 СҮР2С9 У ПАЦИЕНТОВ ПОЖИАОГО И СТАРЧЕСКОГО ВОЗРАСТА И У ЗАОРОВЫХ АОБРОВОАЬЦЕВ ПЕРВОГО ПЕРИОАА ЗРЕАОГО ВОЗРАСТА}

\author{
А. А. Сычев ${ }^{1}$, С. П. БорАовский ${ }^{2}$, В. Э. Никулин ${ }^{2}$, Н. И. Польшина ${ }^{2}$, \\ Г. С. Аникин ${ }^{2}$, К. С. Аанилина ${ }^{1}$, В. В. Смирнов ${ }^{2,3}$ \\ 1 Российская меАицинская акаАемия непрерывного профессионального \\ образования, Москва, Российская ФеАерация \\ 2 Первый Московский госуАарственный меАицинский университет \\ им. И. М. Сеченова, Российская ФеАерация \\ 3 ГНЦ ИнститУт иммУнологиИ ФеАерального МеАико-биологического агентства \\ России, Москва, Российская ФеАерация
}

At the first phase of the research the evaluation of the activity of cytochrome CYP2C9 in 18 elderly and geriatric patients was carried out, mean age of the patients was $71.6 \pm 9.6$ years. At the second phase the efficiency and safety of losartan trial in 18 healthy volunteers of the first period of mature age $26.3 \pm 3.5$ years was evaluated. To evaluate the activity of isoenzyme of cytochrome P450 CYP2C9 the determination of the concentration of active metabolite of Losartan E-3174 in the urine to the concentration of losartan was used. The concentration ratio E-3174 to losartan in elderly and senile patients was $1.84 \pm 0.15$, in healthy young volunteers $-3.28 \pm 0.77$. A statistically significant metabolic E-3174/losartan ratio decrease in elderly and senile patients was demonstrated, which indicates about the decreased activity of CYP2C9 in that age group.

Keywords: drug therapy, drug side effects, CYP2C9 isoform, losartan, elderly people

На первом этапе исследования проводилась оценка активности цитохрома СYР2C9 у 18 пациентов пожи-

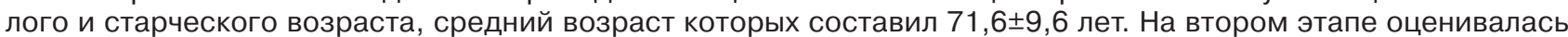
эффективность и безопасность пробы с лозартаном у 18 здоровых добровольцев (26,3 $\pm 3,5$ лет) первого периода зрелого возраста.

Для оценки активности изофермента цитохрома P450 CYP2C9 использовалось отношение концентрации метаболита лозартана E-3174 в моче к концентрации лозартана. Отношение концентраций E-3174 к лозартану у пациентов пожилого и старческого возраста составило $1,84 \pm 0,15$, у здоровых добровольцев молодого возраста - 3,28 0,77 . Было продемонстрировано статистически значимое снижение метаболического отношения Е-3174/лозартан у пациентов пожилого и старческого возраста, что свидетельствует о сниженной активности СYP2C9 в данной возрастной группе.

Ключевые слова: лекарственная терапия, неблагоприятные побочные реакции, СҮР2С9, лозартан, пожилые пациенты, пациенты старческого возраста

$\mathrm{N}$ owadays the percentage of geriatric and elderly people in the whole population tends to grow [7]. According to the data from Russian Federal State Statistics Service the population size of people past retiring age increased by 4 million during the last 10 years. Elderly-dependency ratio of the population in Russian Federation outnumbered $20 \%$ and has stayed at the level of 20.7-20.8\% since 1997 till present. According to some researchers' perspectives, elderlydependency ratio must have increased to $24.8 \%$ by 2016. 
People over age of 60 have 2 times higher frequency of adverse effects, people over age of 70 have it 7 times higher comparing to patients of juvenile age [2].

One of the greatest issues of elderly and geriatric people drug therapy is age-dependent changes of pharmacokinetics and pharmacodynamics of the drugs prescribed [2]. Patients' age is one of the most consequential factors, as it influences many organs' function greatly, liver in particular, where major drug metabolism reactions take place. Therefore exploring drug metabolism changes in liver of aged patients is of great importance for safety of aged patients' drug therapy.

Drugs biotransformation in elderly and geriartric people has been reported to slow down due to liver pulp atrophy, the depletion of active hepatic cells, decreased activity of microsomal enzymes and their perverted metabolism. Expression of isoforms of cytochrome P450 changes with age [8]. Hepatic blood flow is decreased almost by $35-45 \%$ in comparison with that of young and middle aged people. Thus, age-related changes lead to increased drug bioavailability and plasma concentration. At the same time due to renal drug clearance decrease, biological half-life of drugs having both high and low metabolic rates is changed [1].

At the present time various methods are used in order to evaluate drug metabolism in vitro such as breath tests, metabolic ratio counting (MRs), and the most frequently used - clearance counting $(\mathrm{CL})$ using testing drugs.

CYP2C9 is the enzyme that is involved in drug metabolism of such significant drugs as warfarin [9], some anticonvulsants [6] and NSAIDs [10].

Currently several methods of CYP2C9 phenotyping are known.

Tolbutamid test requires administration of $125 \mathrm{mg}$ torbulamid and taking blood samples in 24 hours. After the intake of the drug substance the research of biomaterials is conducted using highly effective liquid chromatography with the mass analysis capabilities of mass spectrometry (HPLC-MS) [4]. This method doesn't take into account metabolic activity of another enzyme isoform - CYP2C19 towards torbulamid, which may lead to inaccurate test data.

Administration of $300 \mathrm{mg}$ phenytoin is also used in order to test CYP2C9 activity.CYp2C9 phenotyping is performed be counting phenytoin concentration and its metabolite, $p$-hydroxyphenyl hydantoin using HPLC-MS [3]. This method, as well as the previous one, doesn't consider metabolic activity of other enzyme isoforms CYP2C19 and CYP3F4 towards phenytoin, which may lead to inaccurate test data.

Losartan test is recommended for CYP2C9 activity definition in vivo by Russian guidelines for studying biotransformation and new drug transporter testing by pharmaceutical companies [11]. The test is based on counting losartan and its active metabolite E-3174 concentration in urine samples. E-3174 is formed mostly by CYP2C9. Another enzyme isoform CYP3F4 activity in losartan metabolism isn't taken into account in this method which may again lead to inaccurate test data concerning CYP2C9 activity.

CYP2C9 was found to be the determinative enzyme in losartan metabolism at its physiological concentration meanwhile CYP3A4 gets involved in losartan metabolism only at its higher concentrations [5]. This discovery was made during oxidation processes test using yeasts and human hepatic microsomal enzymes.

At this stage there are no data concerning CYP2C9 activity changes in elderly and geriatric people in comparison with the first period of mature aged people.
The purpose of this research is to compare CYP2C9 isoenzyme activity in elderly and senile patients and in people of the first period of middle age.

Material and Methods. The clinical study was conducted at the therapeutic department of «Medsantrud» City Clinical Hospital № 23. The design of the research is represented by an experimental study conducted on two groups of patients.

The work was carried out in 2 phases. The first phase evaluated the activity of cytochrome CYP2C9 in elderly and geriatric patients. The study included 18 elderly and senile patients ( 10 women, 8 men), mean age was $71.6 \pm 9.6$ years. All of the patients were corresponding to the following criteria:

Criteria for inclusion into the study: a) senile and elderly age; b) Signed informed consent.

Criteria for exclusion from the study: a) receiving inhibitors and/or inducers of CYP2C9; b) Carriers of 'slow' allele variants CYP2C9*2, CYP2C9*3 (determined by polymerase chain reaction restriction fragment length polymorphism (PCR-RFLP) after DNA extraction from peripheral blood leucocytes); c) acute hepatic (significant increase in liver transaminases and the AST/ ALT ratio $\leq 1$ ) and/or renal failure (progressive increase in serum creatinine concentration of more than 1.5 from standard (172 mg/dL for men, $145 \mathrm{mg} / \mathrm{dL}$ for women) or progressively decreased urine output - less than $0.5 \mathrm{ml} / \mathrm{kg}$ over 6 hours); d) hypersensitivity to the drug or its components, as well as intolerance of study drug; e) any chronic disease that may interfere with the study (malignant neoplasms in the last five years, alcoholism, drug addiction, uncontrolled diabetes mellitus, chronic renal insufficiency, severe airway obstruction); f) 1Mental illness or disability; g) the lack of willingness to cooperate.

In the second phase we evaluated the efficiency and safety of losartan trials in healthy volunteers of the first period of mature age (18 people).

The control group consisted of 18 healthy people of the first period of mature age ( 12 women, 6 men) aged $26.3 \pm 3.5$ years. Persons with any chronic disease, alcohol abuse, and pregnancy, contraindications to receiving losartan or persons permanently taking drugs were not included. All volunteers carried out physical examination, performed routine clinical laboratory tests (ECG, blood count, blood chemistry, urinalysis, studies on HIV, hepatitis viruses $B$ and $C$, Wasserman reaction) as a result of which all parameters were within normal limits.

Inclusion criteria were the absence of a history of allergies, cardiovascular diseases, COPD and endocrine diseases in the control group, acute respiratory viral infections at least 1 month 54 prior to the study, medication of any drugs and supplements at least 1 month prior to the study, any chronic diseases and bad habits, media «slow» allele variants CYP2C9*2, CYP2C9*3 (determined by PCR RFLP after DNA extraction from peripheral blood leukocytes).

All volunteers signed an informed consent.

A total of 12 men and 6 women were included in the pharmacokinetic study of losartan, all of them from the Russian ethnic group.

Determination of the concentration of losartan and E-3174 (active metabolite of losartan) in the urine was performed by HPLC with spectrophotometric detection (PCR-RFLP).

Genotyping of allelic variants CYP2C9*2 and CYP2C9*3 of patients was performed by PCR-RFLP after prior isolation of DNA from peripheral blood leucocytes.

Identification of the ADR was carried out using a questionnaire (a specially designed questionnaire addressed to the study participants on the basis of the ADR, which were listed in the typical clinical pharmacological drug article). 
Statistical analysis of the results was performed using IBM SPSS Statistics 20. To describe the program parameters presented in the form of alternative variables, there were given the number of cases and the proportion of patients (percentage). For a description of the indicators presented in the form of quantitative variables, assuming a normal distribution of the population we used parametric methods of descriptive statistics: sample average value \pm standard deviation $(\overline{\mathrm{x}} \pm \sigma)$. The MannWhitney method was used for statistical processing of the data. To determine the statistical significance in the study we used a paired t-one-sample test for satisfying the requirements of normal (Gaussian) distribution. Differences were considered significant at $p<0.05$. To determine the relationship we were used the Spearman correlation coefficient.

Results and Discussion. According to the study the E-3174/losartan concentration ratio in elderly patients was $1.84 \pm 0.15$. In healthy young volunteers the E-3174/ losartan ratio was $3.28 \pm 0.77$. The concentration of losartan in elderly patients was $517.41 \pm 76.68$. In healthy young volunteers the concentrations of losartan was $587.89 \pm 134.06$. The concentration of the E-3174 in elderly patients was $829.98 \pm 88.11$. In healthy young volunteers the concentration of E-3174 was $1128.09 \pm 202.73$ (Table 1).

Table 1

Mean values of concentrations of E-3174, losartan and their ratio in the test sample based on the standard deviation

\begin{tabular}{|l|c|c|c|}
\hline $\begin{array}{c}\text { Concen- } \\
\text { tration }\end{array}$ & $\begin{array}{c}\text { Elderly } \\
\text { and senile patients }\end{array}$ & $\begin{array}{c}\text { Healthy young } \\
\text { volunteers }\end{array}$ & $\mathrm{P}$ \\
\hline $\begin{array}{l}\text { Losartan } \\
(\mathrm{ng} / \mathrm{ml})\end{array}$ & $517.41 \pm 76.68$ & $587.89 \pm 134.06$ & $\mathrm{p}<0.0001$ \\
\hline $\begin{array}{l}\mathrm{E}-3174 \\
(\mathrm{ng} / \mathrm{ml})\end{array}$ & $829.98 \pm 88.11$ & $1128.09 \pm 202.73$ & $\mathrm{p}<0.0001$ \\
\hline $\begin{array}{l}\text { E-3174/ } \\
\text { Losartan }\end{array}$ & $1.84 \pm 0.15$ & $3.28 \pm 0.77$ & 0.0750 \\
\hline
\end{tabular}

In young patients the E-3174/losartan ratio, the concentration of E-3174 and losartan concentrations were higher than in elderly and senile patients.

A correlation analysis between the CYP2C9 activity (metabolic ratio) and the amount of medication patient received was also conducted. According to the results of the correlation analysis between the number of drugs and CYP2C9 activity Spearman's correlation coefficient was $-0.12 ; \mathrm{P}=0.73$

\section{References}

1. Belousov Y., Leonova M. Osobennosti primeneniya lekarstv v geriatricheskoy praktike. Farmateka. 2008;8:13-19.

2. Denisova T., Malinova L. Klinicheskaya gerontologiya: Izbrannye lektsii. 2008

3. George M., Shewade D. G., Kumar S. V., Adithan C. Effect of anti-tuberculosis therapy on polymorphic drug metabolizing enzyme CYP2C9 using phenytoin as a probe drug. Indian Journal of Pharmacology. 2012;44(4):485488. doi: 10.4103/0253-7613.99314

4. Jetter A., Kinzig-Schippers M., Skott A., Lazar A., Tomalik-Scharte D. [et al.] Cytochrome P 450 2C9 phenotyping using low-dose tolbutamide. European Journal of Clinical Pharmacology. 2004;60(3):165-171. doi: $10.1007 / \mathrm{s} 00228-004-0754-z$

5. Joy M., Dornbrook-Lavender K., Blaisdell J., Hilliard T., Boyette T. [et al.] CYP2C9 genotype and pharmacodynamic responses to losartan in patients with primary and secondary kidney diseases. European Journal of Clinical Pharmacology. 2009;65(9):947-953. doi: 10.1007/ s00228-009-0707-7

6. Klotz U. The Role of Pharmacogenetics in the Metabolism of Antiepileptic Drugs. Clinical Pharmacokinetics. 2007;46(4):271-279. doi: 10.2165/00003088200746040-00001
An assessment of differences in CYP2C9 activity in patients treated with substrates of this isoenzyme, and in patients not taking CYP2C9 substrates was also conducted. The E-3174/losartan ratio in patients treated with substrates of CYP2C9 was $1.93 \pm 0.37$ (Table 2)

Table 2

Descriptive statistics: the ratio of the E-3174/losartan

\begin{tabular}{|l|c|c|c|}
\hline & $\begin{array}{c}\text { Patients who } \\
\text { took CYP2C9 } \\
\text { substrates }\end{array}$ & $\begin{array}{c}\text { Patients who } \\
\text { did't take } \\
\text { CYP2C9 substrates }\end{array}$ & $P$ \\
\hline $\begin{array}{l}\text { E-3174/ } \\
\text { Losartan ratio }\end{array}$ & $\begin{array}{c}1.93 \pm 0.37 \\
{[0.89 ; 2.57]}\end{array}$ & $\begin{array}{c}1.96 \pm 0.33 \\
{[0.72 ; 2.5]}\end{array}$ & 0.9393 \\
\hline
\end{tabular}

The E-3174/losartan ratio in patients who didn't take CYP2C9 substrates was found to be higher $(p=0.94)$ than in patients who took CYP2C9 substrates and makes 1.96 \pm 0.33 .

A research in vivo conducted on 18 patients of elderly or senile age and 18 young volunteers of the first period of middle age showed a statistically significant metabolic E-3174/losartan ratio decrease in elderly and senile patients, which indicates that the CYP2C9 activity in that group is lower than that in young volunteers of the first period of middle age.

There was found no statistically significant difference of enzyme isoform activity in people receiving CYP2C9 substrates comparing with people who didn't receive them during the comparative analysis.

During comparative analysis of other clinical researches the activity of other enzyme $\mathrm{P} 450$ isoforms, in particular CYP2C19, CYP3A4, CYP2E1, CYP2C9, was found to have a tendency to decrease [12].

The conducted research hasn't detected any significant relation between one of the most base cytochrome P450 isoform - CYP2C9 activity and the quantity of drug received.

Conclusions. Having conducted comparative analysis of CYP2C9 activity in elderly and senile people and healthy volunteers of the first period of mature age we found that the activity of CYP2C9 in elderly people has a tendency to decrease. Such changes influence elimination of drugs metabolized by this enzyme isoform, thus prescribing them to elderly and senile patients, without concerning age-related decrease of CYP2C9 activity, may appear to be the reason of adverse side effects which usually lead to increased therapy expenses and higher frequency of hospitalization and death among patients of this age group. The right dose schedule of drugs will help to decrease therapy expenses and increase its efficiency.

7. Osadchikh A., Puzin S., Lavrova D. Problemy invalidnosti v Rossii. Sostoyaniye i perspektivy. 2002.

8. Page C., Curtis M., Walker M. Pharmacology: a clinical approach. 2012.

9. Scordo M., Pengo V., Spina E., Dahl M. L., Gusella M. [et al.] Influence of CYP2C9 and CYP2C19 genetic polymorphisms on warfarin maintenance dose and metabolic clearance. Clinical Pharmacology \& Therapeutics. 2002;72(6):702-710. doi: 10.1067/ mcp.2002.129321

10. Shi S., Klotz U. Clinical use and pharmacological properties of selective COX-2 inhibitors. European Journal of Clinical Pharmacology. 2008;64(3):233-252. doi: 10.1007/s00228-007-0400-7

11. Sychev D. Rekomendatsii dlya farmatsevticheskikh kompany po izucheniyu biotransformatsii i transporterov novykh lekarstvennykh sredstv: dizayn issledovany, analiz dannykh i vneseniye informatsii $v$ instruktsii po primeneniyu. 2009. Available at: http://www.regmed. ru/Content/Doc. aspx?id=26a9128c-ee32-4469-9c64$5 \mathrm{c} 666339049 \mathrm{e}$

12. Tanaka. In vivo age-related changes in hepatic drugoxidizing capacity in humans. Journal of Clinical Pharmacy and Therapeutics. 1998;23(4):247-255. doi: 10.1046/j.1365-2710.1998.00164.x 


\begin{abstract}
About authors:
Sychev Dmitry, MD, DMSc, Professor, corresponding member of Russian academy of sciences; Head of department of clinical pharmacology and therapy; e-mail: dmitry.alex.sychev@gmail.com

Bordovsky Sergey, 5-year medical student; e-mail: Arhont7@bk.ru

Nikulin Vladislav, 5-year medical student; e-mail: texet460@me.com

Polshina Natalia, 5-year medical student; e-mail: Natalya-poshina@yandex.com

Anikin Georgiy, MD, Associate professor at the department of clinical pharmacology and therapy; e-mail: medi321@mail.ru

Danilina Kristina, applicant at the department of clinical pharmacology and therapy; e-mail: kristina90.90@bk.ru

Smirnov Valeriy, CPhs, Head of the laboratory of clinical pharmacology № 73, associate professor at the department of pharmaceutical and toxicological chemistry; e-mail: pharma@bk.ru
\end{abstract}

(c) Ketova G. G., Barysheva V. O., 2017

UDC 615.015154+614.2-082.039

DOI - https://doi.org/10.14300/mnnc. 2017.12087

ISSN - 2073-8137

\title{
PHARMACOGENETIC TESTING ON WARFARIN AND CLOPIDORGEL IN CONDITIONS OF A MULTIPROFILE HOSPITAL
}

\author{
Ketova G. G., Barysheva V. O.
}

South Ural State Medical University, Chelyabinsk, Russian Federation

\section{ФАРМАКОГЕНЕТИЧЕСКОЕ ТЕСТИРОВАНИЕ НА ВАРФАРИН И КАОПИАОГРЕА В УСАОВИЯХ МНОГОПРОФИАЬНОГО СТАЦИОНАРА}

\author{
Г. Г. Кетова, В. О. Барышева
}

\section{Южно-Уральский госуАарственный меАицинский университет, Челябинск, Российская ФеАерация}

In the study 236 patients was included. Decoding of the genotypes was carried out with kits of reagent for determining genetic polymorphisms associated with the metabolism of warfarin or clopidogrel with detection PCR results in real-time; and melting curve analysis, qualitative analysis ("NPO DNA-Technology», Russia). The age mean age of the patients was $57.5 \pm 12.01$ years. Gender differences included $54.6 \%$ male. Clopidogrel sensitivity is influenced by several genetic polymorphisms: ABCB1: CC - 19.1\%, CT - 42.6\%, TT - 31.2\%. CYP2C19*2: GG - 78.7\%, AA $2.1 \%$. CYP2C19*3: GG - $100 \%$. CYP2C19*17: CC $-57.4 \%$, CT $-36.9 \%$, TT $-5.7 \%$. Allelic variants: $1 /{ }^{*} 1-39.7 \%$, ${ }^{\star} 1 /{ }^{*} 2-15.6 \%,{ }^{\star} 2 /{ }^{*} 17-4.3 \%,{ }^{\star} 2 /{ }^{\star} 2-2.1{ }^{*} 1 /{ }^{\star} 17-32.6 \%,{ }^{\star} 17 /{ }^{*} 17-5.7 \%$. Thus, the prevalence of genotypes associated with resistance to clopidogrel in the studied population is $22.0 \%$. The frequency of genotypes associated with high sensitivity to warfarin in the studied population was: CYP2C9* $1 /{ }^{\star} 2-17.9 \%, \mathrm{CYP} 2 \mathrm{C} 9{ }^{\star} 1 /{ }^{\star} 3-13.7 \%, \mathrm{CY}-$ P2C9 *2/ $23-2.1 \%$, AA VKORC $1-21.1 \%$

Keywords: pharmacogenetics, pharmacogenetic testing, warfarin, clopidogrel, personalized medicine

Исследование включило 236 пациентов. Расшифровка генотипов проводилась с помощью наборов реагентов для определения генетических полиморфизмов, ассоциированных с метаболизмом варфарина или клопидогрела, с детекцией результатов ПЦР в реальном времени; анализ кривых плавления, качественный

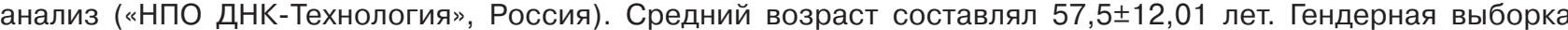
включила 54,6 \% пациентов мужского пола. На чувствительность к клопидогрелу влияли несколько генетических полиморфизмов: АВСВ1: СC - 19,1\%, СТ - 42,6 \%, TT - 31,2 \%; CYP2C19*2: GG - 78,7 \%, AA - 2,1\%; CYP2C 19*3: GG - $100 \%$; CYP2C 19*17: CC - 57,4\%, CT - 36,9\%, TT - 5,7\%. Allelic variants: $1 /{ }^{\star} 1-39,7 \%,{ }^{*} 1 /{ }^{\star} 2-$ $15,6 \%,{ }^{\star} 2 /{ }^{\star} 17-4,3 \%,{ }^{\star} 2 /{ }^{\star} 2-2,1 * 1 /{ }^{\star} 17-32,6 \%,{ }^{\star} 17 /{ }^{\star} 17-5,7 \%$. Таким образом, распространенность генотипов, ассоциированных с резистентностью к клопидогрелу в исследуемой популяции, составляет $22,0 \%$. Частота генотипов, связанных с высокой чувствительностью к варфарину, в исследуемой популяции составила: CYP2C9 *1/*2 - 17,9 \%, CYP2C9 * $1 /{ }^{\star} 3-13,7 \%$, CYP2C9 *2/ $3-2,1 \%$, AA VKORC $1-21,1 \%$.

Ключевые слова: фармакогенетика, фармакогенетическое тестирование, варфарин, клопидогрел, персонализированная медицина

P harmacogenetics and pharmacogenomics aim to establish the influence of genetic factors on drug efficacy and adverse reactions.

Genetic polymorphisms, SNPs (Single Nucleotide Polymorphism) being the most common, are minimal changes in genetic information, present in more than
$1 \%$ of the population, considered to be normal variants, but nevertheless, in certain circumstances, they may have a phenotypic impact. These genetic polymorphisms make an important contribution to the great inter-individual and inter-ethnic variability in drug response [7]. 